Jurnal Pemberdayaan: Publikasi Hasil Pengabdian kepada Masyarakat

Vol. 4, No. 3, Desember 2020, Hal. 319-328

ISSN: 2580-2569; e-ISSN: 2656-0542

DOI: https://doi.org/10.12928/jp.v4i3.2008

\title{
Implementasi Program Kadarzi di Wilayah Kerja Posyandu Agung 2 Sokowaten Dusun Plumbon Kecamatan Banguntapan Kabupaten Bantul Yogyakarta
}

\author{
Teti Sukmawati, Dwi Yulianti, Nabila Fanda Syafitri, Anggi Triya Septiani, Nurhafisah, \\ Syamsu Hidayat \\ Program Studi Kesehatan Masyarakat, Fakultas Kesehatan Masyarakat, Universitas Ahmad \\ Dahlan, Kampus 3 Jl. Prof. Dr. Soepomo Sh Kec. Umbulharjo Yogyakarta. 55164 \\ Email: tetisukma40@gmail.com
}

\begin{abstract}
ABSTRAK
Gizi yang baik merupakan pondasi kesehatan untuk itu perlunya pemenuhan gizi di keluarga, pemenuhan gizi harus dimulai sejak dini yaitu saat mulai dalam kandungan, bayi, balita karena pemenuhan gizi sangat berpengaruh untuk pertumbuhan dan perkembangan. Kadarzi merupakan keluarga yang dapat mengetahui mencegah dan mengatasi permasalahan gizi di dalam suatu keluarga dengan mempertimbangkan lima indicator kadarzi. Jenis penelitian ini merupakan penelitian kuantitatif deskriptif dengan menggunakan sample masyarakat dusun plumbon RT 1-6 dan RT 34 dengan jumlah sample 52 Berdasarkan hasil penelitian yang sudah dilakukan di dapatkan kesimpulan bahwa masyarakat di daerah tersebut belum sepenuhnya menerapkan perilaku Kadarzi. Intervensi yang dilakukan adalah dengan metode penyuluhan kepada masyarakat menggunakan media ceramah, slide power point, poster dan leaflet. Dampak dari intervensi tersebut, adanya peningkatan pengetahuan masyarakat tentang kadarzi khususnya terkait konsumsi suplemen gizi dan vitamin A.
\end{abstract}

Kata kunci: Perilaku Kadarzi, Suplemen Gizi, Vitamin A

\begin{abstract}
Good nutrition is the foundation for health. Therefore, nutrition intake should start early, since the baby develops in the womb up to toddlers. In Indonesia a program called Kadarzi has been implemented to ensure families nutrition intake, however, in reality there were a number of challenges. This intervention aims to examine the implementation of Kadarzi program in Plumbon, a hamlet in the Village of Banguntapan that encompasses neighbourhood (RT) 1-6 and 37. The intervention was carried out through public counseling, using media such as lecture, power point, posters, and leaflets. The result was an increase in public knowledge, particularly in the consumption of nutritional supplement and vitamin A.
\end{abstract}

Keywords: Kadarzi Behavior, Nutritional Supplements, Vitamin A

\section{PENDAHULUAN}

Permasalahan mengenai Gizi merupakan bagian dari terpenting dan sangat mejadi perhatian serius dari pemerintah. Gizi yang baik merupakan pondasi untuk kesehatan dan kesejahteraan masyarakat. Gizi di dalam kelurga sangat berpengaruh bagi pertumbuhan, perkembangan, serta produktivitas masing- masing anggota keluarga. Pemenuhan terhadap gizi seseorang harus dimulai sejak bayi/ balita agar dapat meningkatkan status kesehatan dalam tahap pertumbuhan dan perkembangan di usia dini supaya dapat tumbuh menjadi dewasa yang berkualitas. Pemenuhan gizi tersebut dapat dimulai dari lingkungan keluarga atau biasa disebut dengan istilah KADARZI ( keluarga sadar gizi). KADARZI yang dimaksud adalah keluarga yang bisa dan mampu mengetahui, mencegah dan mengatasi permasalahan gizi setiap anggota 
keluarga. Suatu keluarga dapat dikatakan sudah memenuhi gizi di dalam keluaga atau sudah KADARZI apabila sudah berperilaku gizi yang baik yang sudah di tentukan berdasarkan lima indikator KADARZI yang dicirikan minimal dengan : menimbang berat badan secara teratur, memberikan ASI Ekslusif kepada bayi, makan beraneka ragam, menggunakan garam beryodium, mengkonsumsi suplemen gizi.(Rahmiwati \& Febry, 2015)

Salah satu indikator KADARZI pada bayi/balita yaitu menimbang berat badan secara teratur. Penimbangan balita adalah hal yang penting dilakukan sebagai upaya untuk mendeteksi kasus gizi buruk dan gizi kurang. Penimbangan balita biasanya dilakukan di Posyandu setiap satu bulan sekali. Indikator kedua yaitu memberikan ASI Eksklusif. Pemberian ASI eksklusif yang sangat penting dilakukan dalam rangka pemenuhan zat gizi yang terkandung dalam ASI. Asi eksklusif dapat mencegah resiko mengalami kematian dibandingkan dengan yang tidak mengkonsumsi ASI eksklusif. Ketiga mengenai yaitu asupan gizi . pemberian makanan sangat penting dan dapat menurunkan masalah gizi, dimana anak dengan konsumsi makanan beragam memiliki tingkat kesehtan yang baik. Makanan beragam dapat meningkatkan asupan zat gizi serta menurunkan stunting pada balita. Keempat yaitu menggunakan garam beryodium. Penggunaan garam beryodium dapat menanggulangi gangguan akibat kurang yodium (GAKY). Kelima yaitu mengkonsusmsi suplemen gizi. Suplemen gizi yaitu Vitamin A diberikan agar menurunkan angka kejadian penyakit xeropthalmia akibat rendahnya tingkat KVA (Kekurangan Vitamin A). Suplemen gizi diberikan oleh Pemerintah untuk anak bayi 611 bulan dengan kapsul berwarna biru dan anak balita usia 12-59 bulan dengan kapsul berwarna merah. (Wijayanti \& Nindya, 2017)

Data dari profil kesehatan tahun 2019 menunjukan angka status gizi balita pada tahun 2018 menunjukan 199 Balita gizi buruk, dengan proporsi balita laki-laki sebanyak 101 dan 98 balita perempuan. Prevalensi data angka status gizi buruk tahun 2018 sebesar 0,41\% dan jika dibandingkan dengan angka status gizi buruk tahun 2017 memiliki prevalensi yang sama sebesar $0.41 \%$. Hasil dari data ini menunjukan perlunya kewaspadaan mengingat gizi pada balita dapat menentukan pertumbuhan fisik dan perkembangan kecerdasan balita dimasa depan. Masalah mengenai gizi buruk yang masih tinggi diakibatkan karena masih rendahnya pemberian suplemen gizi bayi/balita yaitu pemberian vitamin A. Pemberian vitamin A sebanyak 2 kali setiap bulan Febuari dan Agustus. Hasil pemberian Vitamin A sebesar 99, 96\% untuk bayi dan $100 \%$ pada balita. Presentase cakupan pemberian vitamin A untuk Puskesmas menunjukan hasil yang masih rendah yaitu pada Puskesmas Banguntapan III (Bantul DINKES, 2019)

Tujuan dari dilakukannya survey lapangan dalam kegiatan Pengalaman Belajar Laoangan ( PBL) adalah mahasiswa dapat mengetahui permasalaha yang ada di masyarakat di daerah tersebut dan dapat melakukan upaya pemecahan masalah yang telah dirundingkan dengan masyarakat terkait dengan prioritas masalah apa yang paling tinggi untuk selanjutnya masyarakat dapat mengetahui atau mendapatkan informasi kesehatan terkait gizi di dalam keluarga khususnya suplemen gizi.

Adanya naskah ini diharapkan dapat menambah pengetahuan mengenai pentingnya mengkonsumsi suplemen gizi khususnya Vitamin A pada bayi ataupun balita. Dengan adanya kegiatan PBL ini kami melihat adanya kurang komunikasi antara kader Posyandu dengan pihak masyarakat tentang bagaimana konsumsi Vitamin A yang diberikan setiap bulan Febuari dan Agustus. Diharapkan dalam pemberian dan pengkonsumsian Vitamin A dikonsumsi ditempat supaya meminimalisisr apabila terjadi kelupaan ataupun kehilangan Vitamin A yang akan diberikan ke bayi/ balita. Banyak yang menjadikan perbandingan bagaimana implementasi program KADARZI yang memerlukan monitoring agar terciptanya Keluarga Sadar Gizi yang diharapkan di awal penciptaan program tersebut. 


\section{METODE}

Metode yang di gunakan dalam kegiatan survey lapangan atau kegiatan Pengalaman Belajar Lapangan (PBL) menggunakan metode penelitian kuantitatif deskriptif. Menurut Sugiyono (2013) metode penelitian kuantitatif merupakan penelitian yang berlandaskan pada filsafat positivism, dipakai untuk meneliti sample di dalam suatu populasi tertentu yang cara penggambilan samplenya dilakukan secara random. Pengambilan sampel menggunakan metode sampel cluster random sampling. Dalam kegiatan pengambilan data di lakukan dalam wilayah cakupan kerja Posyandu Agung II Sokowaten yang mencakup 7 RT yaitu RT 1-6 dan RT 34 di Dusun Plumbon. Penentuan jumlah sampel menggunakan rumus Lemeshow 1999 dalam Murti 2006. Sample tersebut berjumlah 52 Kepala Keluarga. Kegiatan intervensi dilakukan dengan metode penyuluhan pemberian materi terkait Gizi Keluarga khususnya tentang pentingnya konsumsi suplemen gizi. Pentingnya memerikasakan kesehatan anak bayi, balita dan ibu hamil ke Posyandu. Sasaran Kegiatan intervensi terkait suplemen gizi yang dilakukan adalah untuk orangtua bayi, balita dan ibu hamil yang dilakukan pada tanggal 16 dan 17 februaru 2020 di rumah salah satu warga di Dusun tersebut.

\section{HASIL, PEMBAHASAN, DAN DAMPAK}

Kadarzi merupakan keluarga yang berperilaku gizi seimbang dan dapat mampu mengenal, mencegah serta mengatasi masalah gizi pada setiap anggota keluarganya. Menurut data dari profil kesehatan tahun 2019 Keluarga dikatakan memiliki perilaku Kadarzi yang baik apabila sudah menerapkan lima indikator Kadarzi yaitu, menimbang berat badan secara rutin, memberikan ASI eksklusif, makan beraneka ragam, menggunakan garam beryodium dan mengonsumsi suplementasi zat gizi. Menurut Puskesmas ada enam indikator Kadarzi yaitu, menimbangan berat badan secara teratur, memberikan ASI ekslusif, makan beraneka ragam, menggunakan garam beryodium, mengkonsumsi suplemen gizi, dan sarapan pagi, menunjukkan terdapat 2 indikator yang menyebabkan capaian Kadarzi rendah yaitu memberikan ASI eksklusif dan makan beraneka ragam2 . Indikator Kadarzi yang menyebabkan capaian Kadarzi rendah belum tercapainya pemberian ASI eksklusif dan menimbang berat badan secara rutin sesuai target.(Wijayanti \& Nindya, 2017)

Menurut World Health Organization (WHO) yang dikenal sebagai badan kesehatan dunia, mereka menyatakan bahwa masih terdapat daerah-daerah di dunia yang rentan terjadinya kekurangan vitamin A. WHO menyatakan kekurangan vitamin A ini terjadi pada sekitar 190 juta anak usia pra-sekolah di seluruh dunia, terutama di daerah Asi Tenggara dan Afrika.

Pemberian Vitamin A warna biru sejak umur 6 bulan dapat mencegah terjadinya underweight pada balita. Balita yang diberi Vitamin A warna biru sejak umur 6 bulan memiliki peluang $37 \%$ lebih rendah untuk terhindar dari underweight dibanding balita yang tidak diberi Vitamin A warna biru. Untuk mencegah terjadinya underweight pada balita diperlukan upaya untuk mempertahankan dan meningkatkan cakupan pemberian Vitamin A utamanya pada saat pemberian Vitamin A serentak pada bulan Februari dan Agustus. (Muliah et al., 2018)

Vitamin A berfungsi dalam penglihatan normal pada cahaya remang. Di dalam mata retinol, bentuk vitamin A yang didapat dari darah, dioksidasi menjadi retinal. Retinal kemudian mengikat protein opsin dan membentuk pigmen visual merah-ungu (vr.suat purpte) atau rodopsin. Rodopsin ada di dalam sel khusus di dalam retina mata yang dinamakan rod. Bila cahaya mengenai retina, pigmen visual merah-ungu ini berubah menjadi kuning dan retinal dipisahkan dari opsin. Pada saat itu, terjadi rangsangan elektrokimia yang merambat sepanjang saraf mata ke otak yang menyebabkan terjadinya suatu bayangan visual. selama proses ini, sebagian dari vitamin A dipisahkan dari protein dan diubah menjadi retinol.(Zulkifli, 2007)

Penanggulangan anak-anak yang Kekurangan Vitamin A (KVA) di Indonesia, khususnya pada balita 6-59 bulan. Strategi penanggulangan hingga saat ini dilaksanakan melalui 
pemberian kapsul vitamin A dosis tinggi pada bayi, balita dan ibu nifas. Pada balita diberikan dua kali setahun dengan dosis 100.000 IU untuk bayi 6-11 bulan dan 200.000 IU untuk anak 12- 59 bulan dan ibu nifas. Sekitar 10 juta balita di Indonesia beresiko kekurangan Vitamin A dari jumlah target sebesar 20 juta balita.

Berdasarkan hasil pengumpulan data yang diperoleh, didapatkan suatu permasalahan KADARZI di masyarakat daerah Plumbon RT 1-6 dan RT 34, seperti dirangkum pada Gambar 1.

\section{Grafik 1. Distribusi Frekuensi Rekapitulasi KADARZI di RT 1-6 dan RT 34 Dusun Plumbon Febuari Tahun 2020}

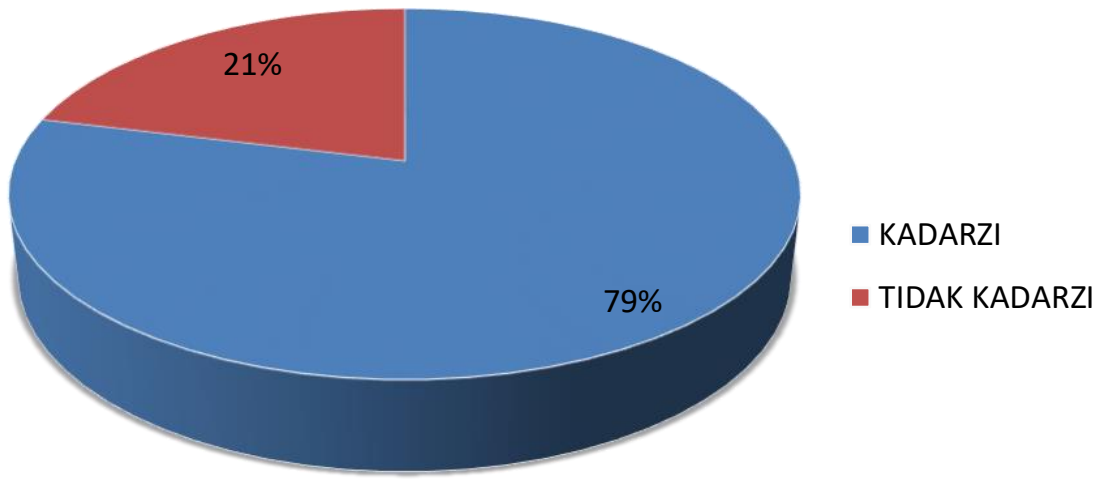

Gambar 1. Distribusi Frekuensi Rekapitulasi KADARZI

Dari hasil rekapitulasi jumlah KADARZI pada RT 1-6 dan RT 34 menunjukan hasil lebih dari setengah sampel menunjukan sudah KADARZI sebesar $79 \%$ dan $21 \%$ masih belum memenuhi kriteria KADARZI.

Banyaknya masyarakat yang telah menerapkan program KADARZI harusnya dapat membantu dalam proses pelaksanaan dalam berbagai tindakan yang akan dijadikan pertimbangan Pemerintah ataupun pihak Puskesmas dalam tindak lanjut program ini. Pihak Pemerintah dan Puskesmas dituntut terus melakukan peningkatan serta pendekatan ke masyarakat agar terus melanjutkan program yang telah berjalan sejak awal supaya tetap berjalan dengan seiring berjalannya waktu. Peran patuhnya masyarakat berperan penting dalam setiap jalannya sebuah program.

Dalam Nugroho (2011), ketepatan sebuah pelaksanaan program apabila adanya ketepatan aktor utama implementasi dari program serta keterlibatan pihak swasta dalam proses pelaksanaannya. Ketepatan lainnya yaitu ketepatan dalam penentuan target program. Ketepatan target yang dimaksudkan adalah respon dari masyarakat dalam melaksanakan program KADARZI. 


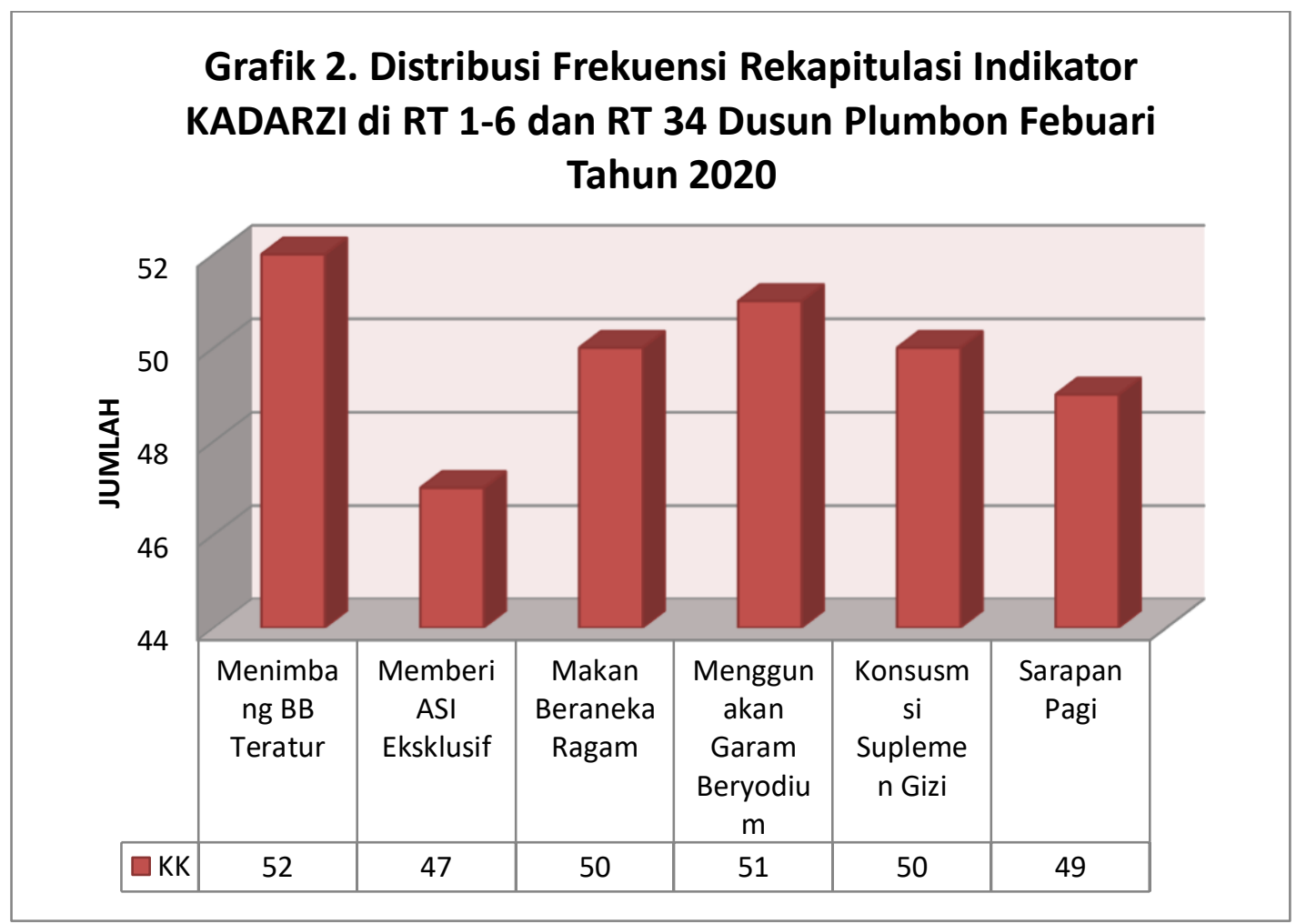

Gambar 2. Distribusi Frekuensi Rekapitulasi Indikator KADARZI

Berdasarkan dari hasil Gambar 2, yaitu distribusi frekuensi rekapitulasi indikator KADARZI di dusun plumbon RT 1-6 dan RT 34 , menunjukan dari 21\% keluarga yang tidak KADARZI mencakup indikator- indikator didalamnya. Indikator yang paing tinggi tidak terpenuhi yaitu memberi ASI eksklusif sebanyak 47 yang melaksankan program dan 5 lainnya belum melaksanakan program. Kedua yaitu indikator sarapan pagi dari $52 \mathrm{KK}$ yang dijadikan sampel 3 yang belum melaksanakan program. Ketiga yaitu masalah makanan beraneka ragam dan konsumsi suplemen gizi yaitu sebanyak $50 \mathrm{KK}$ telah memenuhi kedua indikator dan $2 \mathrm{KK}$ lainnya belum memenuhi indikator tersebut.

Alasan masyarakat paling banyak mengenai pemberian ASI eksklusif dikarenakan banyaknya kesibukan dari sang ibu yang membuatnya tidak cukup waktu untuk memberikan ASI serta kurang dari 6 bulan memberikan ASI, ibu berhenti memberikan ASI. Syarat pemberian ASI dikatakan eksklusif menurut WHO dan UNICEF (dalam Arifa 2016), pemberian ASI direkomendasikan selama 6 bulan pertama sejak bayi lahir tanpa tambahan makanan pendamping dan dilanjutkan makanan pendamping yang tepat sampai dengan usia 2 tahun. Pemberian ASI eksklusif diharapkan mampu menurunkan angka kesakitan dan kematian anak.

Adapaun alasan masyarakat tidak melakukan sarapan pagi yaitu; Tidak ada waktu kebanyakan masyarakat susah bangun pagi. Akibatnya, semua kegiatan pagi hari harus dilakukan terburu-buru, mulai menyiapkan baju untuk pergi bekerja.Selain itu masyarakat malas untuk menyiapkan sarapan karena repot. Sehingga membuat masyarakat berpikir bahwa tidak sarapan pagi itu hanya hal yang bisa atau bukan sebuah masalah sehingga masyarakat tidak mengetahui bahwa banyaknya manfaat dari sarapan pagi.

Sarapan merupakan aktifitas makan di pagi hari yang dibutuhkan oleh manusia, karena mempunyai banyak manfaat, diantaranya dapat menyumbang sekitar 15-30\% kebutuhan gizi per hari, menjadi faktor penting dalam pengaturan energi, memelihara ketahanan fisik dan meningkatkan produktivitas kerja Namun, banyak orang yang tidak melakukan sarapan dengan 
berbagai alasan salah satunya yaitu anak usia sekolah. Padahal anak usia sekolah merupakan kelompok usia yang sedang tumbuh dan mengalami perkembangan otak yang sangat tergantung pada asupan makanan secara teratur sehingga anak usia sekolah diharuskan untuk sarapan setiap hari.

Salah satu indikator KADARZI adalah makan beraneka ragam. Aneka ragam makanan diperlukan, karena tidak ada satu jenis makanan yang mengandung semua zat gizi dan kesehatan yang dibutuhkan, kecuali ASI. Nasi, misalnya, kaya akan karbohidrat, tapi miskin akan vitamin, mineral, lemak dan serat. Karena itu harus dimakan dengan lauk pauk, seperti ikan, daging, telur, tahu dan tempe. Lauk pauk kaya akan protein dan lemak. Sayur dan buah kaya akan vitamin, mineral dan serat. Selain zat gizi, dalam buah dan sayur juga kaya akan antioksidan. Alasan lain pentingnya konsumsi aneka ragam makanan adalah karena jenis dan Jumlah zat gizi yang terkandung dalam tiap jenis makanan berbeda-beda. Dengan makan beragam, kekurangan zat gizi dari satu makanan akan dilengkapi oleh makanan lain. Mengkonsumsi makanan yang beraneka ragam akan menjamin terpenuhinya kecukupan sumber zat tenaga, zat pembangun dan zat pengatur. Keanekaragaman makanan dalam hidangan sehari-hari yang dikonsumsi, minimal harus berasal dari satu jenis makanan sumber zat tenaga, satu jenis makanan sumber zat pembangun dan satu jenis makanan sumber zat pengatur. Penganekaragaman pangan merupakan salah satu pilar utama dalam upaya penurunan masalah pangan dan gizi. Hal tersebut menunjukkan bahwa penganekaragaman makanan konsumsi pangan bagi masyarakat merupakan aspek penting bagi perwujudan SDM yang berkualitas (Aditianti et al., 2016).

Konsumsi suplemen gizi yang dimaksudkan dalam program KADARZI adalah Vitamin A untu bayi/balita dan Fe untuk ibu hamil. Dari hasil tersebut masih ada bayi/balita yang belum rutin mengkonsumsi Vitamin A. Hal yang kami dapatkan dari lapangan menunjukan bahwa Vitamin A telah diberikan ke ibu yang anak tetapi dalam pengkonsumsiannya tidak diawasi kader Posyandu karena Vitamin A diberikan dan dibawa pulang untuk dikonsumsi dirumah. Jika bayi/ balita tidak datang posyandu diberikan kepada salah satu warga yang dekat rumah warga tersebut tanpa melihat langsung sang bayi/balita benar-benar mengkonsumsi Vitamin A tersebut. Hal ini dapat memicu kelupaan ataupun kehilangan Vitamin A. Jika pun kehilangan sebenarnya tetap diberikan lagi apabila ibu meminta ke kader, inilah yang membuat pemborosan dalam penyetokan Vitamin A, seperti tampak pada Gambar 3.

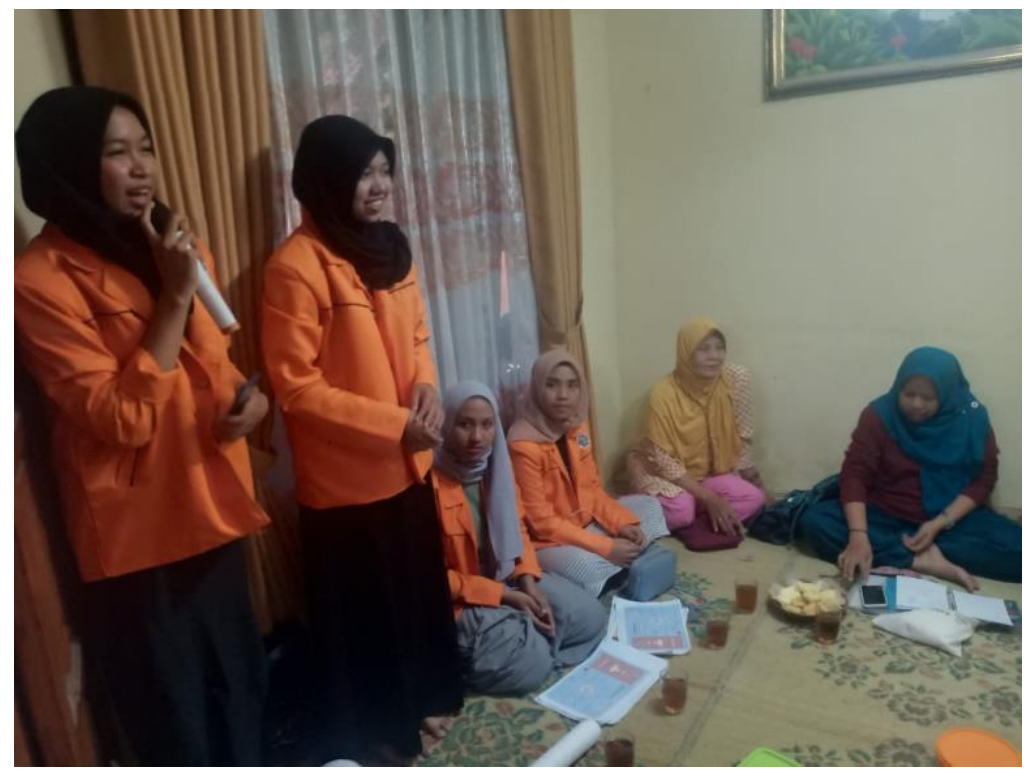

Gambar 3. Kegiatan Intervensi 
Kekurangan vitamin A merupakan penyebab kebutaan yang paling sering ditemukan pada anak-anak dan membuat 250.000-500.000 orang anak menjadi buta setiap tahunnya dan separuh diantaranya akan meninggal dunia dalam tahun tersebut. Lebih kurang 150 juta anak lain menghadapi peningkatan resiko kematian dalam usia kanak-kanak akibat penyakit infeksi yang disebabkan oleh status vitamin A yang tidak memadai (Adriani, 2019).

Alasan keluarga yang tidak atau belum membawa balitanya ke posyandu saat pemberian kapsul vitamin A secara serentak dikarenakan keluarga tidak mengetahui jadwal pemberian kapsul vitamin A. Hal tersebut terjadi karena balita jarang dibawa ke posyandu sehingga keluarga tidak memperoleh informasi jadwal pemberian kapsul vitamin A. Selain itu hal tersebut juga dikarenakan keluarga belum mengetahui tentang pentingnya manfaat vitamin A pada anak (Muliah et al., 2018).

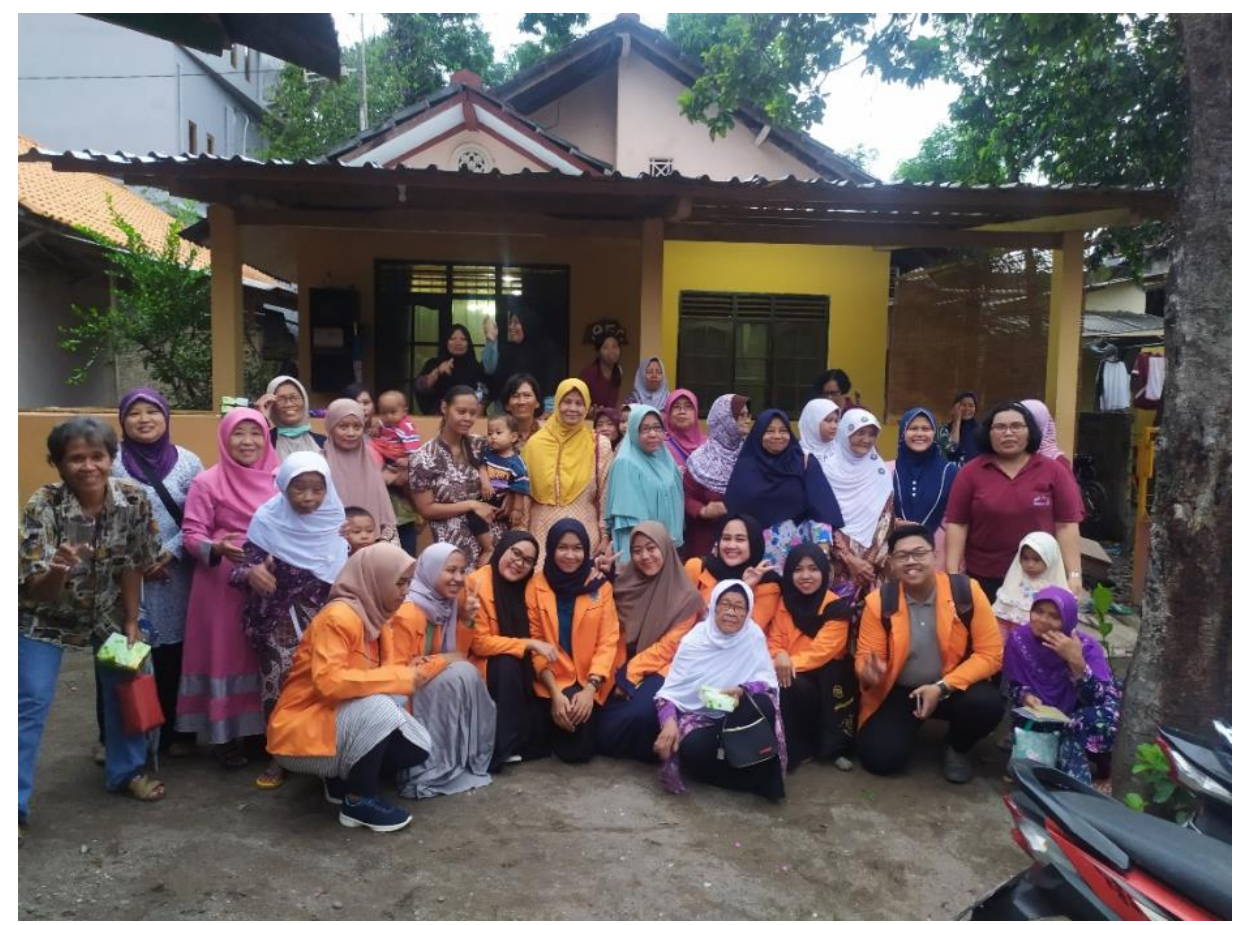

Gambar 4. Foto bersama dengan para masyarakat

Dengan adanya permasalahan ini kami mahasiswa FKM dibantu dengan mahasiswa Farmasi memberikan sedikit pemaparan materi mengenai pentingnya pengkonsumsian Vitamin A untuk bayi/balita sebagai pencegahan kesakitan dan kematian pada bayi/balita. Dalam proses pemamparan materi kami menggunkan media ceramah dan dilanjutkan tanya jawab. Media yang kami gunakan adalah poster, leaflet, brosur dan ppt.

Dalam pelaksanaan kegiatan intervensi para peserta (Kepala Rumah Tangga) memberikan respon yang positif, mereka terlihat sangat antusias dengan kegiatan intervensi ini karena kegiatan ini dapat menambah pengetahuan terkait dengan indicator Rumah Sehat dan STBM dengan harapan di laksanakan intervensi ini agar dapat diterapkan dikehidupan seharihari (Gambar 4 dan 5). 


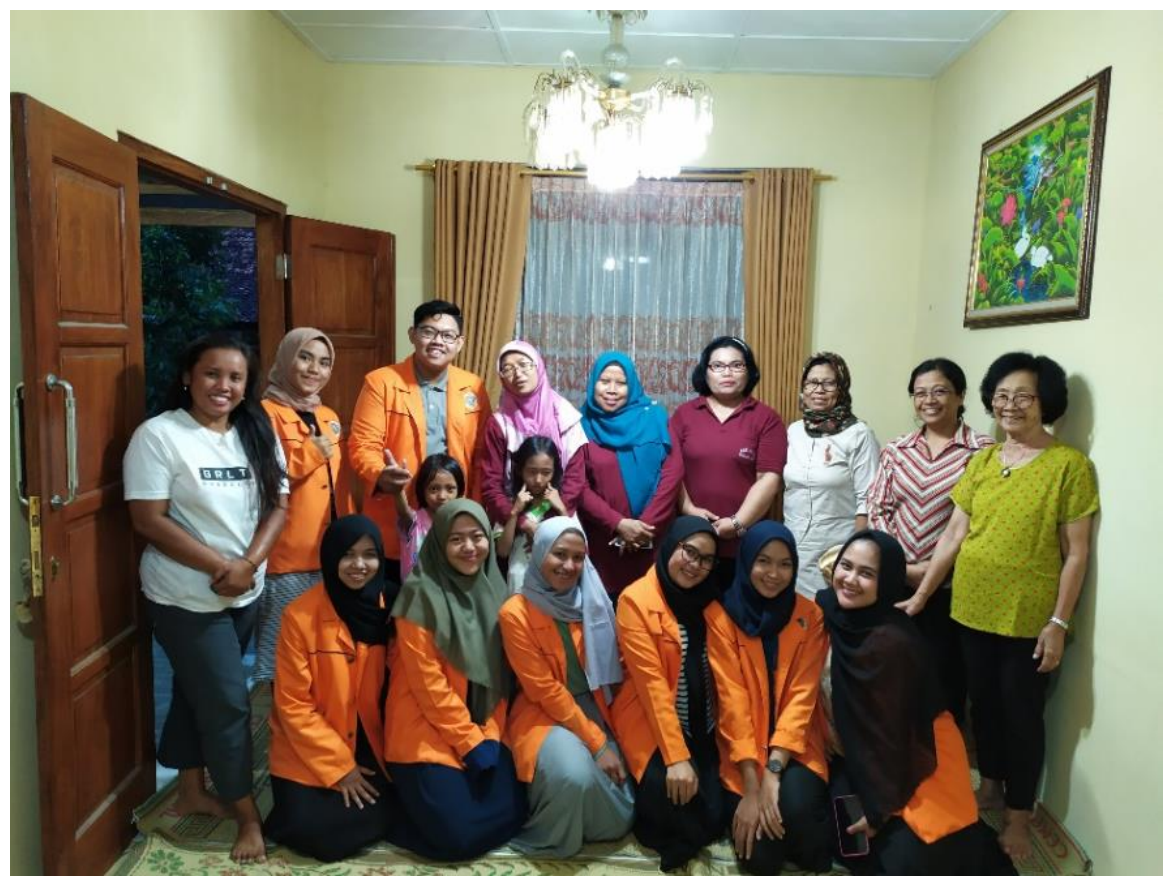

Gambar 5. Foto bersama dengan para kader kesehatan dan tuan rumah

\section{KESIMPULAN}

Berdasarkan hasil yang didapatkan selama melaksanakan Pengalaman Belajar Lapangan di wilayah kerja Posyandu Agung II Sokowaten dapat disimpulkan bahwa tidak ber PHBS dengan persentase sebesar $60 \%$ dari $52 \mathrm{KK}$ yang dijadikan sampel. Capaian indikator PHBS yang belum terpenuhi yaitu tidak merokok di rumah tangga, sarapan pagi, cuci tangan pake sabun dan pemberantasan jentik. Sedangkan untuk indikator KADARZI dengan persentase sebesar 79\% dari $52 \mathrm{KK}$ telah memenuhi kriteria KADARZI. Capaian indikator KADARZI yang belum terpenuhi yaitu Memberikan ASI Eksklusif, Sarapan Pagi, Makan Beranega Ragam dan Konsusmsi Suplemen Gizi.

Untuk pemecahan masalah melalui intervensi kami melakukan edukasi secara langsung tentang kekurangan pada indikator KADARZI dan PHBS tersebut, seperti dampak tidak mengkonsumsi suplemen gizi dan tidak mencuci tangan dengan baik dan kami juga menggunakaan media ppt, poster, leaflet dan banner.

\section{UCAPAN TERIMAKASIH}

Penulisan Naskah Publikasi ini tidak lepas dari berbagai pihak. Oleh karena itu, penulis menyampaikan ucapan terimakasih kepada Dekan Fakultas Kesehatan Masyarakat Ibu Lina Handayani, S.KM, M.Kes, Ph.D atas ijinnya atas dilaksanakannya kegiatan Praktek Belajar Lapangan (PBL), Bapak M. Syamsu Hidayat, M.Sc.Ph.,D selaku dosen pembimbing PBL atas bimbingan dan motivasinya, Ibu Sri rahayu selaku ketua Kader Posyandu Agung 2 atas bimbingan dan bantuannya, Bapak Aris purnomo selaku kepala Dukuh Dusun plumbon atas izin dilaksanakannya kegiatan PBL khususnya Posyandu Agung 3, dan Segenap Dosen dan Staf di lingkungan Fakultas Kesehatan Masyarakat Universitas Ahmad Dahlan.

\section{DAFTAR PUSTAKA}

Aditianti, A., Prihatini, S., \& Hermina, H. (2016). Pengetahuan, Sikap dan Perilaku Individu Tentang Makanan Beraneka Ragam sebagai Salah Satu Indikator Keluarga Sadar Gizi (KADARZI). Buletin Penelitian Kesehatan, 44(2), 117-126. 
https://doi.org/10.22435/bpk.v44i2.5455.117-126

Adriani, P. (2019). Faktor-Faktor Yang Berhubungan Dengan Pemberian Vitamin a Pada Balita Di Wilayah Kerja Puskesmas Kandai Kota Kendari. Jurnal SMART Kebidanan, 6(1), 20. https://doi.org/10.34310/sjkb.v6i1.234

Bantul DINKES. (2019). Narasi Profil Kesehatan 2019. 1-47.

Muliah, N., Wardoyo, A. S., \& Mahmudiono, T. (2018). Hubungan Frekuensi Penimbangan, Penggunaan Garam Beryodium, Dan Pemberian Vitamin a Dengan Kejadian Underweight Pada Balita Di Provinsi Jawa Timur. Media Gizi Indonesia, 12(1), 40. https://doi.org/10.20473/mgi.v12i1.40-46

Rahmiwati, A., \& Febry, F. (2015). Jurnal Ilmu Kesehatan Masyarakat korelasi perilaku kadarzi terhadap status gizi balita di puskesmas simpang timbangan indralaya tahun 2014 correlation of kadarzi behavior on the nutritional status toddlers in health centers simpang timbangan indralaya pen. 195-201

Wijayanti, S., \& Nindya, T. S. (2017). Relationship of Kadarzi (Family Conscious Nutrition) Behavior Practice to Nutritional Status of Children Under Five Years in Tulungagung District. Amerta Nutrition, 1(4), 379-388. https://doi.org/10.20473/amnt.v1.i4.2017.378-388

Zulkifli, A. (2007). Skrining Masalah Gizi Akibat Kekurangan Vitamin A. 1-45. 
